order, sculptors fashioned out of the two hillocks living likenesses of elephants.

After this His Majesty Shah Jahān resumed his march and encamped at Naushahra."

Note.-Shah Jahän saw the elephants when on his way from Lahore (I.O. MS. 856, Ethé's, 332, p. 223, top line). He was marching by way of Bhimbar and Pìr Panjāl. He left Bhimbar on May 22, 1634, and arrived at Chauki Hati, which was 4 kos distant. Next day he reached Naushahra, which is $3 \frac{1}{2}$ kos distant. From Naushahra he went on to Chingiz Hati, the Changas Serai of the map, and so on to Rajaur. It was while on the way from Chauki Hati to Naushahra that he saw the statues. The incident is also mentioned in the $B \bar{a} d s h \bar{a} h n \bar{a} m a, \mathrm{I}$, pt. ii, p. 18 of the Bib. Ind. edition. I must admit that if two of the elephants were of Jahangir's time, Șālih's rhetoric about the antique and mysterious origin of the statues is out of place.

H. Beveridge.

\title{
The Later Kushans
}

The rule of the Kushans in Northern India lasted for some four hundred and fifty years from the middle of the first century B.C. to the end of the fourth century A.D.; and it passed through three stages. Kanishka, descending from Gandhāra and the fastnesses of the Hindu Kush, overturned the local rulers, and established the dominion of the Kushans as far as Benares and Ghazipur. Sixty or seventy years later his kingdom underwent a temporary eclipse under the encroachments of the Pahlavas and Sakas ; but Vāsudeva restored the sovereignty for a time in the central and eastern parts of Kanishka's dominions and in the Eastern Panjāb, perhaps also in Kashmir. This is the first act of the drama.

The second act begins with the reign of Wema Kadphises, the Kushan king of Bactria, in the third 
quarter of the first century A.D. He reconquers the whole country once conquered by Kanishka, adopts the worship of Śiva, and governs his new territories through a Kushan deputy, who was in the first instance a member of the royal house. This government of Northern India by Kushan deputies lasts for some fifty years or more, apparently down to the time of Pan Yong's report, c. A.D. 125. During this period the power of the Kushan kings of Bactria was at its height, and it is not easy to conceive how any revolt of the provinces south of the Paropamisus and the Himalayas could have successfully taken place. Moreover, we have the direct evidence of Pan Yong to the contrary. I therefore conclude that this second period of Kushan history lasted through the first quarter of the second century A.D. But barbaric Asian kingdoms seldom retain the allegiance of distant provinces for long; and in the course of the second century A.D. Kābul, Kashmir, and the Panjāb became independent Kushan states. With their secession the third period of Kushan history in India begins; and it is the history of these Later Kushans which forms the subject of this paper.

For this stage we have two accounts: the first is by Ptolemy, and dates from the middle of the second century of our era; the other is in the Chinese history, the Wei Lio, and dates from the middle of the third century.

Ptolemy's divisions of the country are tribal and geographical, not political ; they are as follows:-

A. The valley of the Indus formed part of IndoScythia. This Indo-Scythia extended above Attock as far north as Embolima, which is usually identified with Amb in the Hazara District.

B. Ptolemy next enumerates the various tribes which lived between the lower course of the Käbul River and the Indus, viz. Lamghān, Souastēnē (Udyāna, now Swat),

JRAS. 1913. 
the Daradai or Dards where the mountains were "of surpassing height".

C. We have the Himalayan countries, Kaspeiria or Kashmir, and Kylindrinē, i.e. the hills between Kashmir and the sources of the Jamnā and the Ganges.

D. In the foothills and in the plains skirting them, between the Indus and the Bidaspes (Hydaspes or the Jhelam River), lay the Arsa (U-ra-sa) territory, and here on both banks of the Jhelam dwelt the Pandoouoi, whose chief town was Sāgala, i.e. Siālkoṭ. ${ }^{1}$

E. The Kaspeiraioi or Kashmiris possessed the rest of the Panjāb and all the country eastward and south as far as the banks of the Jamnā. On the Jamnā bank was

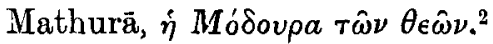

Thus Ptolemy sharply demarcates the Śakas and Pahlavas of the Lower Indus, with their Central Asian or Iranian allies, from the hillmen and the people of the Central and Eastern Panjāb. These last are all included under the term Kaspeiraioi or Kashmiris, who must. therefore have been the ruling race. How far the warlike hill tribes between the Kabul River and the Indus, or along the foot of the hills as far east as Sialkot, may have acknowledged the suzerainty of the monarchs of Kashmir or of Bactria, Ptolemy does not tell us. They probably did so, since they struck no coins, but they seem then as now to have preserved their tribal unity and

1 For the identification of Sāgala, Sãkala, with Siālkot see Dr. Fleet's article in the Acts of the Oriental Congress of Algiers, 1905, Indian Section, p. $164 \mathrm{ff}$.

2 Ptolemy's Geography, vii, 42-55 ; McCrindle's trans., pp. 104-36. McCrindle (p. 109) says: "In the time of Ptolemy the kingdom of Kashmir was the most powerful state in all India. The dominions subject to its sceptre reached as far south as the range of the Vindhyas, and embraced, together with the extensive mountain region wherein the great rivers of the Panjāb had their sources, a great part of the Panjāb itself, the courses of the Jamnā and the Upper Ganges. So much we learn from Ptolemy's description." For this remark see also Ind. Ant., vol. 13, p. 346, where McCrindle's translation of Ptolemy was first published. 
much of their tribal independence. Thus Ptolemy's description reminds us very much of the state of the country when it was conquered by Wema Kadphises. We read in the History of the Later Han that the Panjāb possessed many towns, and was divided into many petty states, each under its own petty Rãjah, but all acknowledging one sovereign. ${ }^{1}$ But whether the frontier hill tribes of Ptolemy's day admitted the rule of a foreign sovereign or not, the rest of the Panjāb formed one large and noble kingdom, larger than that of Ranjit Singh in the nineteenth century.

Kashmir appears as a separate country in Ptolemy. It may have been a separate state. But if so, the rulers of Kashmir and the Panjāb must have been closely allied.

The Wei Lio was written between A.D. 239 and $265 .^{2}$ It says: "Le royaume de $\mathrm{Ki}$-pin (Cachemire), le royaume de Ta-hia (Bactriane), le royaume de Kao-fou (Kaboul), le royaume de T'ien-tchou (Inde), ... tous dependent de Ta Yue-che." 3 of the kingdom of Kiu-li (also called Li-wei-to or Pei-li-wang, which must all be different names for Magadha), it is said: "Les Yue-che les ont asservis et leur ont imposé des taxes." 4 The History of the Later Han told us that the Yue-che had made Magadha a subject state. It was still subject in the middle of the third century. We see, then, that, while down to the time of Pan Yong, c. A.D. 125, the whole of the Panjāb had been subject to the Bactrian king and was ruled by Kushan deputies, in the middle of the second century the greater part of it was ruled by a king or people popularly known as Kashmiris. In the middle of the third century Ki-pin (Kashmirr) ${ }^{5}$ and the Panjāb were independent of each

1 JRAS. 1912, p. 678.

2 T'oung pao, 1905, p. $520 . \quad{ }^{3}$ Ibid., p. $538 . \quad$ Ibid., p. 551.

5 Almost all Sinologists are agreed that in the centuries immediately before and after the beginning of the Christian era $K i$-pin meant Kashmir ; in the seventh century of our era it ordinarily, "although not invariably, meant Kapiśa, or North-Eastern Afghanistan " (V. Smith, 
other; but both were ruled by Yue-che, i.e. Kushan, kings. The Kaspeiraioi of Ptolemy must obviously have been Kushans, so far at least as the governors were concerned. On the other hand, they must have been naturalized and Hinduized, if they were popularly confounded with Kashmiris proper. I have elsewhere ${ }^{1}$ quoted evidence to show that this later Indian Kushan kingdom was a great and powerful one, since its ruler was one of the four great devaputras of the world, the one who was rich in elephants. We may expect to find our knowledge of its history, and our conception's of its greatness, much increased by the excavations now in hand at Taxila and elsewhere.

When did the Indian Kushans become independent of Bactria? Ptolemy helps us, although not quite conclusively, to an answer. It must have been in the second century of our era, and apparently between A.D. 125, the approximate date of Pan Yong's report to the Emperor Ngan, and A.D. 150, the approximate date of Ptolemy's geography. Ptolemy's evidence would suggest that the process was a gradual one. Kashmir and the Eastern Panjāb became independent first. They were the most distant provinces, and had at one time formed the kingdom of Văsudeva. They seem to have established their independence before the middle of the second century a.D. During the last half of the same century the remaining possessions of the Bactrian Kushans fell away. However this may be, there is distinct evidence to show that the later Indian Kushans kept alive the memory of Kanishka and professed to revive his line; for they put the names of Kanishka and Văsudeva on their

Early History, p. 235, n. 1). Chavannes in his translation of the Wei Lio, which I have quoted above, makes it Kashmīr. But Dr. Herrmann, the latest writer on the subject, holds that it was Gändhära. He has not given us his reasons, but it is just possible that in the Wei Lio Gāndhāra may be meant.

1 JRAS. 1912, p. 682. 
coins, ${ }^{1}$ and imitated Vāsudeva's coinage. The retention of the legends was possibly due in part to the inability of the engravers to express other names in Greek letters; but it may also be taken as an assertion that the dynasty was a legitimate one.

To this dynasty we may assign Kanishka II of the Ara inscription, who is admittedly distinct from the great Kanishka. ${ }^{2}$ To Kanishka II the inscription gives the imperial titles Mahāa $\bar{a} j a$, Rājātirāja, and Devaputra, with a fourth into which we need not enter here. And it lays some stress upon his birth, by mentioning his father's name. It is possible that the father was the last of the Bactrian deputies, who, having long ruled the country, became virtually independent. The son, more bold, made himself a king, became the founder of the later Kushans, and no doubt claimed royal descent from his great ancestor, Kanishka I. Some vague reminiscence of this Kanishka II seems to have survived among the Buddhists, since Täranātha mentions a certain Kanilca, and carefully distinguishes him from the great Kanishka whom he places much earlier. ${ }^{3}$ This Kanika, he says, reigned long in Mālava and Țili. Tāranātha's evidence by itself is perhaps not of any very great value, but in this case it happens to be confirmed: that there was a second Kanishka is certain: and his reign was long, if the year 41 of the Ara inscription is to be taken as a regnal year.

I propose then to reconstruct this period of history somewhat as follows: Wema Kadphises governed the whole country which he and his father had conquered south of the Himalayas and the Hindu Kush, through a member of the royal family known to us as the "Nameless King". Meantime the descendants of Kanishka

1 Rapson, "Indian Coins" (Grundriss), §74, p. 19.

2 Fleet, "The Question of Kanishka" : JRAS. 1913, p. $95 \mathrm{ff}$.

${ }^{3}$ Schiefner, Täranātha, pp. 89-90. It seems hopeless to construct any precise chronological system out of Tāranātha's. 
and Vāsudeva survived as local magnates in Northern India. When a member of the royal line of Bactria was no longer fortheoming for the post of viceroy, a member of the same Kushan gens must have taken his place, and nothing could be more natural than to appoint as governor a resident Kushan chief possessed of Jocal influence, and the descendant of a line of ancient Kushan kings. In the course of time this Kushan governor, of the line of Väsudeva, long left to himself, becomes practically independent. On his death his son, or sons, throw off all allegiance to the declining power of Bactria and proclaim themselves kings. Members of the family in time establish themselves as monarchs in all the territory that remained to Bactria south of the Hindu Kush. They show their independence by rejecting the coinage of the Bactrian Kushan kings of the Kadphises line, whose sovereignty they have shaken off. They imitate, instead, the coinage of their ancestor Vāsudeva, and they appeal to their subjects as the rightful heirs of the great Kanishka, a name to conjure with. But between their coinage and that of Vàsudeva there is a gap, and a considerable time, perhaps five or six decades, must have elapsed, during which viceroys directly appointed by Bactria ruled the country. This sketch probably represents a very fair approximation to what actually happened.

I pass to the later history of these Kushans. Before the middle of the third century of our era, when the Wei Lio was written, the Kushan kingdom on the south of the Hindu Kush and the Himalayas had split up into three independent, although apparently allied, states, whose rulers boasted their descent from the glorified Kanishka. Of each of these states we have some incidental notices. The separation of Kābul from North-Western India was probably the first step towards the dissolution of the Kushan power. The separation of the two is reflected in the coinage. Rapson says: "(1) the coins bearing 
OHPO on the rev., with type, Siva and his bull Nandi, derived from the earlier Kuṣana types of Vāsudeva, belong rather to the Kabul Valley: they were imitated by the Scytho-Sassanians; (2) those with AP $\triangle O x P O$, and type, seated goddess, belong rather to the more eastern portion of the Kușana dominions: they were imitated by the Kidāra Kuṣanas and by the Guptas." 1

Regarding the relations of the Käbul Kushans with the Sassanian monarchs of Persia we have various notices. When Varahran II (A.D. 275-92) engaged in the subjugation of Seistan, c. A.D. 280, his arms seemed to threaten the independence of Kābul; a desultory war ensued; and his armies are said to have been massed on the Indian frontier when the Roman emperor Carus invaded Mesopotamia in A.D. 283. ${ }^{2}$ Varahran's grandson Hormisdas II (A.D. 301-9), who may have learnt from his father's experience the wisdom of conciliating his Scythic neighbours, espoused the daughter of the King of Käbul, and this marriage was celebrated as one of the chief events of his reign. The trousseau of the bride, the product of the looms of Kashmir, was remarkable for its splendour, and was considered worthy of especial mention in the pages of Mirkhond. ${ }^{3}$ A Kashmir shawl, the first ever seen in Europe, had already excited the admiration of the Romans. It formed a part of the presents with which the Sassanian monarch Varahran I (A.D. 272-5), the timorous ally of Zenobia, attempted to avert the anger of Aurelian after the capture of Palmyra (A.D. 274), and Aurelian considered it so valuable that he dedicated it in the temple of Jupiter Capitolinus. ${ }^{4}$ As

1 Rapson, "Indian Coins" (Grundriss), \$ 74, p. 19.

2 Rawlinson, Seventh Oriental Monarchy, pp. 108-9; Gibbon, c. xii (Smith's ed., vol. ii, pp. 54-5).

3 Rawlinson, op. cit., pp. 140-1.

4 Vopisc. Vit. Aurel., c. 29 (Script. Hist. Aug.) : " pallium breve purpureum lanestre, ad quod cum matronæ atque ipse Aurelianus jungerent purpuras suas, cineris specie decolorari videbantur ceteræ, divini comparatione fulgoris. Hoc munus rex Persarum ab Indis 
Varahran told the Roman emperor that such shawls were common in Persia, there must have been at that time an active commerce between Persia and Kashmir.

The alliance of Hormisdas with Käbul marked the beginning of a long period of international amity. The coinages of the Sassanians and the later Kushans bear evidence of the intimate relations which subsisted between them ; ${ }^{1}$ and when Sapur II besieged Amida in A.D. 350, Indian elephants, and perhaps Indian troops, served under his command. ${ }^{2}$

Meanwhile the Kushan dominion in North-Western India seems to have fallen into gradual decay. Of this we have various indications. When the author of the Wei Lio wrote, Magadha was still a tributary state. But by A.D. 320 the Guptas had firmly established their power in Magadha, and that apparently without fear of opposition from the Kushan Devaputras. ${ }^{3}$

We also find that the Kunindas (Kunets) who occupied the upper reaches of the Satlej where it bursts into the plains, and the Yaudheyas of Bhawalpur at the lower end of the stream, revive their coinage of copper, which had

interioribus sumptum Aureliano dedisse perhibetur, scribens: sume purpuram, qualis apud nos est." The colouring of the shawl and the woollen texture show that it came from Kashmir, a country which even in the time of the Early Han, i.e. in the first century B.c., was reported to be famous for its artistic handiwork. The dyes of Kashmir were unrivalled until quite late in the nineteenth century; so a shawlmerchant, a Frenchman, once informed the present writer.

1 Rapson, "Indian Coins" (Grundriss), $\$ \S 74,75$, p. 19 ; Rawlinson, Seventh Oriental Monarchy, p. 141, n. 1.

2 Rawlinson, op. cit., pp. 176-7 ; Am. Mar. xix, c. 7 ; Gibbon, c. xix (vol. ii, p. 408).

3 The Devaputra was rich in elephants-an epithet more applicable to the ruler of the Panjäb than to the kings of Kashmīr and Käbul. When the Kushan empire broke up it would appear from Samudragupta's Allahabad inscription, which mentions the Devaputras, Shāhis, and Shähānushähis among the rulers who did respectful service to him, as if each king had appropriated to himself one of the former imperial titles. Devaputra in that case became the peculiar title of the sovereign of North-Western India, while we know that the Turki rulers of Gandhära appropriated to themselves the title of Shāhi. 
been in abeyance since the days of the Greek princes; and their new coinage imitates the coinage of the Kushans. Numismatists refer these coins to the third and fourth centuries A.D. ${ }^{1}$ The country, therefore, on either bank of the Satlej must have become independent of the Kushans, while the Yaudheyas seem to have extended their rule over much of Northern Rājputāna and the adjoining districts of the Panjāb. ${ }^{2}$ In the fourth century Samudragupta boasts that he had made both the Yaudheyas and the Mădrakas tributary to him (c. A.D. 350). ${ }^{3}$ The Mādrakas had their capital at Sāgala, i.e. Siālkoṭ; they therefore replace Ptolemy's Pandoouoi. Samudragupta also says that he received the homage of the "Devaputras, Shähis, and Shāhānushāhis"." These three represent Kushan kings: and we are naturally tempted to identify them with the three Kushan kingdoms mentioned in the Wei Lio; namely the three kingdoms of the Panjāb, Kābul, and Ki-pin or Kashmīr.5 But the Devaputra kingdom of the Panjāb must by this time have lost most. of its power and become of very limited extent.

After this we hear no more. of it. When Fa Hian traversed the Panjāb on his journey to Mathurā, he found many kings who did honour to Buddha and obeisance to the Buddhist monks, ${ }^{6}$ but he says nothing of a paramount lord. As, however, he is equally remiss in neglecting to mention the great Gupta king Chandragupta II, we can scarcely lay any great stress on his silence. Fa Hian brings us down to A.D. 400 . In the fifth century we have the irruptions from Tokharistan, where the Juan-Juan had driven out the Kushans from their capital of Lan-che

1 Rapson, "Indian Coins" (Grundriss), $\$ \S 50,60$.

2 V. Smith, JRAS. 1897, p. 887.

3 Ibid., p. 889. For Sāgala = Siālkot, see note 1 on p. 1054 above.

- Fleet, CII., vol. iii, The Gupta Inscriptions, p. 14.

5 Possibly, as I have said, the Ki-pin of the Wei Lio may be Gandhāra, and the Eastern Panjāb and Kashmīr may have formed a single state.

"Legge, "Record of Buddhistic Kingdoms"( Travels of Fa Hian), p. 42. 
in Badakhshan, and forced them to retire to Po-lo (probably Balkh) in the south of Bactria. ${ }^{1}$ One of these fugitive Kushans, who called himself Kidāra on his coins, but who was known to the Chinese as $K i$-to-lo, crossed the Hindu Kush, and established his rule over Gandhāra and the adjoining country, including Kashmir. Some fifty years later, $c$. A.D. 475 , the people called Houa by the Chinese, Hūnas by the Indians, White Huns by the Byzantine historian Procopius, but still better known in the West as Ephthalites ${ }^{2}$ from the name of their king, having conquered Käbul, poured at the head of the hordes of Central Asia into India. The descendants of $K i$-to-lo fled to the fastnesses of Chitral and Gilgit; the power of the Kushans had come to an end, and with the advent of the Hūns a new chapter of history begins.

J. KenNEDY.

\section{Numeral Systems of the Timeto-Burman Dialects}

\section{Errata}

1. In JRAS. 1913, p. 317, 1. 2, Lakher is included among the dialects which have a complete system. This is wrong. It uses a base hraw for numbers from ten to nineteen, while sheu is the base for higher numbers.

2. On p. 335 the statement is made: "At six comes a break. Karenni, Yintale, and Mano have a form three, three. They form seven as three, three, one; eight as four, three; nine as four, three, one." There are three words in Karenni: so, used with or as numeral bases; sö, low tone, is three; so, high tone, is ten. Six is sö so. Seven is sö so na ta. Eight is lwi (four) so. Ten is sō; twenty is nö sö. Nine is lwi so na ta. So, without

${ }^{1}$ Chavannes, T'oung-pao, sér. II, vol. viii, No. 2, p. 188 (pp. 41-2, n. 2, of reprint).

3 Other variations are Hephthalites and Nepthalites. Cidaritæ is another name. 